\title{
FINANCIAL VIABILITY OF CIRCULAR BUSINESS MODELS IN TYRE RECYCLING INDUSTRY IN LATVIA
}

\author{
Inga Uvarova ${ }^{1}$, PhD candidate; Dzintra Atstaja², Dr.oec., Prof.; Viola Korpa ${ }^{3}$, Dr.sc.soc. and \\ Miks Erdmanis ${ }^{4}$, Mg.sc.administr. \\ ${ }^{1,2,4}$ BA School of Business and Finance, ${ }^{1}$ University of Liepaja, ${ }^{3}$ Riga Stradins University
}

\begin{abstract}
The end-of-life (EOL) tyre recycling industry in Latvia is encountering economic and sustainability challenges, which require solutions by various stakeholders. Improvement of tyre waste management and recycling is important within the context of sustainability and the new streamlining of circular business models. Its importance is also recognized at the European Union level in relation to the further strategic goals and the European Green Deal. In addition, the tyre recycling industry in Latvia demonstrates a relatively unfavourable financial situation, which is one of the most significant factors hindering the introduction of new circular business models. The aim of this research is to clarify the challenges related to the financial viability of tyre recycling companies adopting the new circular business models. The main research methods are literature review, semistructured in-depth interviews, case studies and financial analyses. There are large stocks of EOL tyres and on average just $50 \%$ of them are recycled. The tyre waste management companies are not motivated to supply EOL tyres to recycling companies. On the other hand, due to various reasons, most of the tyre recycling companies are not working with their maximum production capacity. The research results reveal that the tyre recycling companies mostly run traditional and inefficient business models that require large operating costs and ensure comparatively low profitability. In order to enable more efficient and environmentally friendly tyre recycling process, the companies should implement new, investment intensive technologies. Yet, they face critical issues of liquidity and financial returns. Major conclusions are related to the necessity to develop several business models interlinked within one portfolio thus ensuring the manufacturing of various products with higher added value and quality. This may maximise the profits and improve the financial viability of tyre recycling business models.
\end{abstract}

Key words: circular business models, entrepreneurship, financial viability, tyre recycling.

JEL code: M19, L26, L65

\section{Introduction}

The tyre recycling industry in Latvia is unprofitable with the traditionally applied business models that have high operational costs. Some waste management companies are not interested in recycling of tyres, instead they are collected in various storage units and occasionally illegally discarded. This justifies the need to investigate the challenges and reasons that hinder the tyre recycling industry to introduce and adopt new circular business models providing environmentally responsible solutions. The aim of this paper is to clarify the challenges related to the financial viability of tyre recycling companies adopting the new circular business models. The main empirical research question is What is the financial performance of tyre recycling companies and what are the main obstacles interfering the development of new, financially viable circular business models. The main tasks of this research are as follow: 1) to investigate what are the theoretical interpretations and discourses related to the circular business models and recycling; 2) to describe the general characteristics of the tyre recycling companies in Latvia; 3) to assess the financial performance of tyre recycling companies and identify the main obstacles that interfere the development of new, financially viable circular business models.

The hypothesis provided - introduction of new circular recycling business models may improve the financial viability of tyre recycling companies. 
The research is based on the literature review, semi-structured in-depth interviews, case studies and financial analyses.

\section{Research results and discussion}

\section{The circular economy and circular business models}

The Circular Economy (CE) is focusing on the extension of the lifecycle of products and materials as long as possible and exploring options to utilize the waste as a valuable resource in the manufacturing of other products (De Souza et al., 2020; Sehnem et al., 2019a; Uvarova et al., 2019a, Kircher et al., 2017; EC, 2015). Also, the reduction of consumption of dwelling natural resources and replacing the chemical substances with environmentally friendly materials have dominated the researches in this area (EC, 2019; UN, 2019; Lahti et al., 2018; Adams et al., 2017; EMF, 2012; Daly, 1991; Boulding, 1966).

The above propositions regarding the CE lead to a debate about the circular business models (CBM) on how to integrate the CE principles on the enterprise or micro-business level. This has become increasingly complex question, as many of the world's major industries try to shape their services and products towards the CE. Although CBMs have been actively discussed over the past five years, there are still relatively small number of practical and scientifical studies in this domain (Scarpellini et al.,2020; Avila-Gutierrez et al., 2020).

The idea of the CBM owns its origins to the "Porter's hypothesis" formulated in 1990s, as well as to the development of ecodesign, environmental responsible production and total quality environmental management concepts (Porter, 1991; Hall, 1993; Porter\&Linde, 1995; McAloone\& Evans, 1996; Mizuki et al, 1996; Melnyk et al., 2001). The "Porter's Hypothesis" assumes that implementing green solutions in companies can boost productivity, innovation and competitiveness (Porter, 2011; Porter \& Linde, 1995; Jirgens \& Atstaja, 2017), which is still relevant in the context of CBM. Other researchers advocated the importance examining the company waste disposal costs against the possible revenue from the recycled or reused parts (Mizuki et al., 1996). Notably, this is an important foundation for recycling based CBMs. In 2001, researchers (Melnyk et al., 2001) revealed that companies usually understand "environment reasonable manufacturing" as recycling or material substitution, however detailed investigation of the performance of these companies showed that they also apply such principles as redesign, rebuilding, remanufacturing and reuse. Nowadays these principles are actively described as " $3 \mathrm{R}$ - reuse, reduce, recycle" and more "Rs" principles in CBMs (Uvarova et al., 2019a; Liu et al., 2017; Benton et al., 2015).

During this period of time, research has explored environmental protection as an element of corporate strategy and its impact on business performance, profit capturing, market value, risk management, recognition and assessment by investors, and other benefits. Also, previous researches reveal that in spite of the benefits from integrating environmental aspects into a policy or a strategy, there were insufficient interest by entrepreneurs to integrate environmental aspects into business (Funk, 2003; Lo \& Sheu, 2007). Today, the debate on CBM, its implementation opportunities and its impact on business performance is on the agenda of scientists and practitioners (Sehnem et al., 2019b Uvarova et al., 2019a, Blomsma et al., 2019; Hofmann, 2019; Atstaja et al., 2017). Now CBM can be considered as a subcategory of the discussion topics about sustainable business models and business model innovations (Uvarova et al., 2019a; Hofmann, 2019), highlighting an importance of CBMs in scientific disciplines of a business management, and not just in environment economics comparing to the past. 
Summarising, CBM can be defined as business models that incorporate the principles of the CE thus contributing to the business restructuring towards sustainability and through that ensuring new opportunities for a growth of productivity, efficiency and competitiveness of the company.

\section{Financial performance of the tyre recycling companies}

According to the available data, there are 8 companies in Latvia that have acquired the permit of the State Environmental Service for the tyre recycling with the operating capacity more than 500 tonnes per year (Table 1). It should be mentioned that there are other companies with comparatively smaller operating capacity (less than 200 tonnes per year), they are not included in the analyses as does not significantly contribute to this industry.

Table 1

The overview of tyre recycling companies

\begin{tabular}{|c|c|c|}
\hline Company & $\begin{array}{l}\text { Capacity, } \\
\text { t/per year }\end{array}$ & Description \\
\hline $\begin{array}{l}\text { 1. SCHWENK LATVIJA Ltd. } \\
\text { (previously CEMEX Itd) }\end{array}$ & $\begin{array}{l}\text { Max: } 11000 \\
\text { Actual used: } \\
7500\end{array}$ & $\begin{array}{l}\text { SCHWENK LATVIJA is the cement manufacturer, which uses the EOL } \\
\text { tyres as an alternative material for heating. As other manufacturing } \\
\text { sectors are prevailing within SCHWENK LATVIJA, it is considered as the } \\
\text { consumer of EOL tyres and not a recycling company. Therefore, it is not } \\
\text { included in the financial analyses. Though this company is discarding } \\
\text { the largest share of tyres thus seen as an important in the whole tyre } \\
\text { waste management sector. }\end{array}$ \\
\hline 2. ECO Baltia vide Ltd. & Max: 8000 & $\begin{array}{l}\text { This is the only company ensuring waste management and collection, } \\
\text { and tyre recycling. This company is not included in the financial } \\
\text { analyses as the EOL tyre recycling plant was set-up and launched on } \\
\text { August } 2019 .\end{array}$ \\
\hline 3. ECO STOCK Ltd. & $\begin{array}{l}\text { Max: } 730 \\
\text { Actual: info not } \\
\text { available }\end{array}$ & $\begin{array}{l}\text { This company has received the permit to use EOL tyres for the } \\
\text { production of a pyrolysis oil. However, the annual financial reports } \\
\text { reveal that this company is not operational as it has not demonstrated } \\
\text { the revenues in the financial accounts till 2018. Thus, this company is } \\
\text { not included in the financial analyses. }\end{array}$ \\
\hline 4. AK LRPMK Ltd. & $\begin{array}{l}\text { Max: } 1643 \\
\text { Actual: info not } \\
\text { available }\end{array}$ & $\begin{array}{l}\text { This company recycle the EOL tyre using the pyrolysis technology for } \\
\text { producing a pyrolysis oil. Although this company has received the } \\
\text { permit for the tyre recycling since } 2015 \text {, the annual financial reports } \\
\text { reveal that it is operational since } 2017 \text { when demonstrates actual } \\
\text { revenues in the financial accounts. }\end{array}$ \\
\hline 5. E-DAUGAVA Ltd. & $\begin{array}{l}\text { Max: } 4500 \\
\text { Actual used: } \\
1000\end{array}$ & $\begin{array}{l}\text { This company uses both the mechanical tyre recycling process and the } \\
\text { pyrolysis technology for production of a pyrolysis oil from the EOL tyres. } \\
\text { This company combines two tyre recycling business models within one } \\
\text { portfolio. }\end{array}$ \\
\hline 6. MAKROL Ltd. & $\begin{array}{l}\text { Max: } 1380, \\
\text { Recycled: } 600 ; \\
\text { Vulcanised: } 780\end{array}$ & $\begin{array}{l}\text { This restores the largest part of EOL tyres with the vulcanisation } \\
\text { process. The smaller part of tyres is mechanically processed into the } \\
\text { rubber chips. }\end{array}$ \\
\hline 7. VVV RECYCLING Ltd. & $\begin{array}{l}\text { Max: } 6000 \\
\text { Actual used: } \\
1500\end{array}$ & $\begin{array}{l}\text { This company as the result of the EOL tyre recycling produces the } \\
\text { rubber granules and sells them to company which manufactures rubber } \\
\text { coverings. } \\
\text { This company has introduced the circular business model innovation } \\
\text { (CBMI) within the industry by offering new value proposition with an } \\
\text { innovative high value-added product for the new customer segment. }\end{array}$ \\
\hline 8. R-TECHNOLOGY Ltd. & $\begin{array}{l}\text { Max: } 6000 \\
\text { Actual used: } \\
1000\end{array}$ & $\begin{array}{l}\text { This company is included in the financial analyses just on } 2017 \text { and } \\
2018 \text { as the ensure tyre recycling since summer } 2018 \text {. Both ( } 2017 \text {; } \\
2018 \text { ) years, included in the analyses in order to provide a comparison } \\
\text { of the situation before and after the launch of tyre recycling. } \\
\text { This company produces the rubber for sports and playground coverings, } \\
\text { which as well can be considered as the CBMI with a new value } \\
\text { proposition to new various customer segments. }\end{array}$ \\
\hline
\end{tabular}

Source: created by authors based on the information of SES (2019a) and MoEPRD (2019)

According to MoEPRD (2018), not all companies, that has received the permit, are actually operating in the tyre recycling. Also, the research confirms the company ECO STOCK Ltd. does not have revenues and it is not operating in the period of the analyses.

This research shows an important development transition in the industry in the last 3 years, when 3 out of 8 companies have launched the tyre recycling production with new modern technologies. 
This is partly facilitated by the public support provided for the development and introduction of the green manufacturing technologies.

As described above in the table, five tyre recycling companies were selected for the financial analysis. The period of the financial analyses is from 2013, when most of the companies have started their operations in tire recycling, till 2018 with last approved annual financial reports available. Some of companies have launched the tyre recycling in last 3 years, but as being important in the sector they are included in the financial analyses.

The level of the profitability characterises the ability of an enterprise to generate the financial return form the business and the effectiveness of the use of assets and invested equity (Lesakova, 2007). The net profitability ratios show that in general the tyre recycling companies run inefficient business models with large operating costs ensuring comparatively low return in profit. When excluding VVV Recycling with the extremely marginal value of ratio, the average net profitability shows improvements in last 2 years reaching positive value in 2018 (Table 2).

Net profitability of tyre recycling companies in Latvia

\begin{tabular}{|c|c|c|c|c|c|c|c|}
\hline Company & 2013 & 2014 & 2015 & 2016 & 2017 & 2018 & Trend line \\
\hline AK LRPMK & & & & & $12 \%$ & $14 \%$ & \\
\hline E-DAUGAVA & $-4 \%$ & $-0,4 \%$ & $22 \%$ & $-9 \%$ & $13 \%$ & $24 \%$ & \\
\hline MAKROL & $6 \%$ & $7 \%$ & $-55 \%$ & $-72 \%$ & $-50 \%$ & $-13 \%$ & \\
\hline WV RECYCLING & $-2803 \%$ & n/a* & $-5620 \%$ & $-334 \%$ & $-211 \%$ & $-55 \%$ & \\
\hline R-TECHNOLOGY & & & & & $0,07 \%$ & $11 \%$ & \\
\hline Average & $-934 \%$ & $3 \%$ & $-1884 \%$ & $-138 \%$ & $-47 \%$ & $-4 \%$ & \\
\hline $\begin{array}{r}\text { Average excl. } \\
\text { VVV Recycling }\end{array}$ & $1 \%$ & $3 \%$ & $-17 \%$ & $-40 \%$ & $-6 \%$ & $9 \%$ & \\
\hline
\end{tabular}

* This ratio can not be calculated as the turnover constitute 0

Source: author's calculations based on Lursoft, 2019

It can be concluded, that in general, the tyre recycling companies operate with losses. Yet the situation is improving in last two years, when 3 out of 5 companies have performed with positive profit. This can be related with investments, including the public support, in new technologies which improves the efficiency and performance. Also, companies - VVV Recycling and R-technologies have introduced innovative circular business models to manufacture products with higher added value which allows the widening of customer segments and increasing sales with the new value proposition of innovative products.

The return on assets (ROA) ratio is used to analyse, how successfully a company can use its assets for generating the revenues and also shows the companies' position or competitiveness level against the competitors (Jewell \& Mankin, 2011; Selling \& Stickney, 1998).

Table 3

Return on Assets (ROA) of tyre recycling companies in Latvia

\begin{tabular}{|l|c|c|c|c|c|c|c|}
\hline Company & $\mathbf{2 0 1 3}$ & $\mathbf{2 0 1 4}$ & $\mathbf{2 0 1 5}$ & $\mathbf{2 0 1 6}$ & $\mathbf{2 0 1 7}$ & $\mathbf{2 0 1 8}$ & Trend line \\
\hline AK LRPMK & & & & & $21 \%$ & $26 \%$ & \\
\hline E-DAUGAVA & $-3 \%$ & $-0,32 \%$ & $16 \%$ & $-5 \%$ & $11 \%$ & $16 \%$ & - \\
\hline MAKROL & $3 \%$ & $3 \%$ & $-12 \%$ & $-11 \%$ & $-11 \%$ & $-8 \%$ & - \\
\hline VVV RECYCLING & $-10 \%$ & $-2 \%$ & $-4 \%$ & $-5 \%$ & $-12 \%$ & $-16 \%$ & $>$ \\
\hline R-TECHNOLOGY & & & & & $0,01 \%$ & $10 \%$ & \\
\hline \multicolumn{1}{r|}{ Average } & $-3 \%$ & $0,23 \%$ & $-0,30 \%$ & $-7 \%$ & $2 \%$ & $6 \%$ & \\
\hline
\end{tabular}

Source: author's calculations based on Lursoft, 2019 
Companies with the higher ROA (Table 3) run traditional business models, for instance, producing a pyrolysis oil or mechanically redeploying EOL tyres in rubber chips as the material for heating. The financial analyses show that most of the business models are not efficient having the negative or low profitability. Relatively large operating or production costs causes the negative net profit and, in some companies, even the gross profit.

The financial analyses of each company provide some conclusions regarding each of tyre recycling companies and the financial viability of the business model applied. AK LRPMK has become operational just in last 2 years of analyses. Since then this company still demonstrates comparatively small amount of the cash that may negatively affect the cash flow. This company shall increase the revenues and cash. The diversification of the tyre recycling technologies and introduction of additional products instead of just manufacturing the pyrolysis oil shall improve the financial viability of AK LRPMK. Although the ROA is high, this is due to the relatively small amount of assets. Also, the lack of long-term assets and comparatively large amount of short-term liabilities may affect the credit capacity and ability of attract external funding for adopting new investment intensive technologies.

The net profitability and other financial ratios of E-DAUGAVA are improving noticeably in last two years. Yet, the negative gross profit causes concerns. The portfolio of two well performing circular business models puts this company as the leading within this industry ensuring the largest amount of the turnover, net profit, long-term assets, equity and highest profitability ratios. Yet, this company should consider CBMI and new products, especially assuming the competition by new growing competitors, like R-TECHNOLOGY, and increasing environmental requirements towards the pyrolysis technologies.

The financial analyses of MAKROL reflects the financial viability problems of a business model applied, in particular, the low amount of a cash, the negative net profit and profitability ratios. As the consequences, the operation has been partly restricted for this company since the beginning of 2019 till the recovery of the financial capacity of this company (SES, 2019b). In 2018, the financial situation is stabilising, but still is negative. From the CE perspective the tyre restoration is positive as it extends the lifetime of the EOL tyres, but it appears not efficient with low profitability ratios and require manufacturing of innovative products.

Regarding VVV RECYCLING despite the losses, there is relatively sufficient amount of the cash. During all years of the analyses, the negative net and gross profit does not sound for the financially viable business model. The comparatively remarkable growth of the turnover in 2018 improves the profitability situation of this company, but still it is possessing a threat for restrictions in further operation. This leads to the conclusion that production of just one innovative product does not ensure a sufficient level of the profitability. The specifics of the tyre recycling require the adoption of additional new business models that would complement the existing business model.

R-TECHNOLOGY is new, but promising company in terms of the financial viability. From one hand two years are too short period for the assessment, but still this company demonstrates stunning increase of the turnover, the net and growth profit, and increasing profitability ratios. As this company has introduced innovations within the tyre recycling, it should have strong competitive advantage in forthcoming years. This company has adopted one new circular business models, but the success lies in the manufacturing of various innovative products for different customer segments. 


\section{Conclusions, proposals, recommendations}

1) This research confirms the hypothesis that new circular business models improve the financial viability of the tyre recycling companies, and for that the development of new innovative products is important.

2) The contemporary discussions of researchers and policy makers proves the high importance of this topic not just on the macro, but as well on the micro (business management) level.

3) The tyre recycling companies in Latvia run traditional business models with the low profitability, but companies having several business models combined within one portfolio or introducing CBMI with different innovative products for various customer segments demonstrate better financial results.

4) Further investigation is needed to analyse new perspectives of the development of the CBMs, identifying new products and industries relevant for the industrial symbioses with the EOL tyre recycling products.

5) Further research is necessary about the feasibility and viability of new tyre recycling circular business models that ensure higher profitability ratios for the businesses and encourage the industry for revolutionary re-generation.

\section{Acknowledgements}

Many thanks for the opportunity to conduct and publish this research to BA School of Business and Finance (Latvia) with a research project "Management of Circular Business Models and Projects within Economy of Latvia", and Liepaja University (Latvia) with the project "Promotion of research, innovation and international cooperation in science at Liepaja University (No 1.1.1.5/18/1/018)". This article ensures approbation of some findings of the PhD thesis of Inga Uvarova and more detailed results of this research will be reflected in the PhD Thesis.

\section{Bibliography}

1. Adams, K., Osmani, M., Thorpe, T., \& Thornback, J. (2017). Circular Economy in Construction: Current Awareness, Challenges and Enablers. Proceedings of the Institution of Civil Engineers - Waste and Resource Management, 170 (1), p.15-24.

2. Atstaja, D., Susniene, R., Startiene, G., \& Gabrevics, L. (2017). Evolution from Eco-Friendly Solutions Implementation in an Enterprise. Economic Science for Rural Development Conference Proceedings, No. 44.

3. Avila-Gutierrez, M. J., Martin-Gomez, A., Aguayo-Gonzalez, F., \& Lama-Ruiz, J. R. (2020). Eco-Holonic 4.0 Circular Business Model to Conceptualize Sustainable Value Chain Towards Digital Transition. Sustainability, 12(5), p.1-32.

4. Benton, D., Hazell, J., \& Hill, J. (2015). The Guide to the Circular Economy: Capturing Value and Managing Material Risk. Do Sustainability. Oxford, UK.

5. Boulding, K. (1966). The Economics of the Coming Spaceship Earth. In H. Jarrett (ed.). Environmental Quality in a Growing Economy, Baltimore, MD: Resources for the Future/Johns Hopkins University Press. New York, USA, p. 3-14.

6. De Souza, F. F., Ferreira, M. B., Saraceni, A. V., Betim, L. M., Pereira, T. L., Petter, R. R. H., Pagani, R.N., De Resende, L.M.M., Pontes, J., \& Piekarski, C. M. (2020). Temporal Comparative Analysis of Industrial Symbiosis and Opportunities of Circular Economy in a Business Network. Sustainability, 12(5), p. 1-18.

7. Ellen MacArthur Foundation (EMF), (2012). Towards the Circular Economy: Economic and Business Rationale for an Accelerated Transition (No. vol. 1). Ellen MacArthur Foundation.

8. European Commission (EC), (2015). Communication from the Commission to the European Parliament, the Council, the European Economic and Social Committee and the Committee of the Regions. Passing the loop An EU action plan for the circular economy. Brussels, 2.12.2015.

9. EC (2019). Communication from the Commission to the European Parliament, the Council, the European Economic and Social Committee and the Committee of the Regions. The European Green Deal. Brussels, 11.12.2019.

10. Funk, K. (2003). Sustainability and Performance. MIT Sloan Management Review, 44(2), pp. 65 - 70.

11. Hall R. (1993). The Soul of the Enterprise: Creating A Dynamic Vision for American Manufacturing. New York, NY: Harper Business 
12. Hofmann, F. (2019). Circular Business Models: Business Approach as Driver or Obstructer of Sustainability Transitions? Journal of Cleaner Production, 224, pp. 361-374.

13. Jewell, J. J., \& Mankin, J. A. (2011). What is Your ROA? An Investigation of the Many Formulas for Calculating Return on Assets. Academy of Educational Leadership Journal, 15, pp. 79-91.

14. Jirgens, M., \& Atstaja, D. (2017). Development of Environmental Regulations and Benefits on Enterprises. Economic Science for Rural Development Conference Proceedings (No. 44), p. 248-255.

15. Kirchherr, J., Reike, D. \& Hekkert M. (2017). Conceptualizing the Circular Economy: An Analysis of 114 Definitions. Resources, Conservation and Recycling, 127, pp. 221-232.

16. Lahti, T., Wincent, J., \& Parida, V. (2018). A Definition and Theoretical Review of the Circular Economy, Value Creation, and Sustainable Business Models: Where Are We and Now Where Should Research Move in the Future? Sustainability, 10(8), p. 2-19.

17. Lesakova, L. (2007). Uses and Limitations of Profitability Ratio Analysis in Managerial Practice. In International Conference on Management, Enterprise and Benchmarking, pp. 1-2.

18. Liu, L., Liang, Y., Song, Q., \& Li, J. (2017). A Review of Waste Prevention Through 3R Under the Concept of Circular Economy in China. Journal of Material Cycles and Waste Management, 19(4), pp. 1314-1323.

19. Lo, S. F., \& Sheu, H. J. (2007). Is Corporate Sustainability a Value-Increasing Strategy for Business? Corporate Governance: An International Review, 15(2), pp. 345-358.

20. Lursoft (2019). Annual financial reports, retrieved from: www.lursoft.lv, accessed: 01.12.2019.

21. McAloone, T. C. \& Evans S. (1996). Integrating Environmental Decisions into the Design Process. In 3rd International Seminar On Life Cycle Engineering. CIRP, Verlag Industrielle Organisation, .96, pp. 83-90.

22. Melnyk S.A., Handfield R.B. \& Catalogne R.J. (2001). Integrating Environmental Concerns into the Design Process: The Gap between Theory and Practice. IEEE Transactions on Engineering Management 48(2), pp. $189-208$.

23. Mizuki, C., Sandborn, P. A., \& Pitts, G. (1996, May). Design for Environment-a Survey of Current Practices and Tools. Proceedings of the 1996 IEEE International Symposium on Electronics and the Environment. ISEE1996, pp. 1-6.

24. Mont, O. K. (2002). Clarifying the Concept of Product-Service System. Journal of Cleaner Production, 10(3), pp. 237-245.

25. MoEPRD (Ministry of Environmental Protection and Regional Development of Latvia), (2019). Public information, retrieved from: www.varam.gov.lv. Access: 11.12.2019.

26. MoEPRD (2018). Informativais zinojums par nolietoto riepu apsaimniekosanu, retrieved from: http://tap.mk.gov.lv/mk/tap/?pid=40449470. Access: 11.02.2020.

27. Porter M.E. (1991). America's Green Strategy, Scientific American, p. 168.

28. Porter, M.E., \& Van der Linde, C. (1995b). Toward a New Conception of Environment-Competitiveness Relationship, Journal of Economic Perspectives, 9(4), pp. 97-118.

29. Saleem, Q., \& Rehman, R. U. (2011). Impacts of Liquidity Ratios on Profitability. Interdisciplinary Journal of Research in Business, 1(7), p.95-98.

30. Sehnem, S., Vazquez-Brust, D., Pereira, S. C. F., \& Campos, L. M. (2019a). Circular Economy: Benefits, Impacts and Overlapping. Supply Chain Management Vol. 24 No. 6, pp. 784-804.

31. Sehnem, S., Campos, L. M., Julkovski, D. J., \& Cazella, C. F. (2019b). Circular business models: level of maturity. Management Decision Vol. 57 No. 4, pp. 1043-1066.

32. Selling, T. I., \& Stickney, C. P. (1989). The Effects of Business Environment and Strategy on a Firm's Rate of Return on Assets. Financial Analysts Journal, 45(1), pp. 43-52.

33.SES (State Environmental Service of Republic of Latvia), (2019a). Public information, retrieved from: www.vvd.gov.Iv. Access: 03.12.2019.

34.SES (2019b). Permit for Category B Polluting Activity No.LI16IB0005 (MAKROL Itd.), retrieved from: http://www.vvd.gov.Iv/izsniegtas-atlaujas-un-licences/a-un-batlaujas/?company_name=makrol\&pollution_category=\&pollution_id=\&org_id=\&CLS_Garbage_ID=\&CLS_G

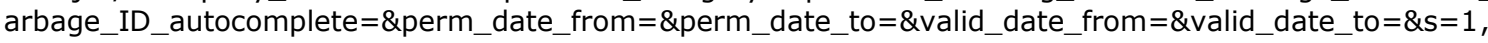
access: 11.12 .2019

35. Scarpellini, S., Marin-Vinuesa, L. M., Aranda-Uson, A., \& Portillo-Tarragona, P. (2020). Dynamic Capabilities and Environmental Accounting for the Circular Economy in Businesses. Sustainability Accounting, Management and Policy Journal.

36. United Nations (UN) (2019), The Sustainable Development Goals Report 2019. United Nations, retrieved from: https://unstats.un.org/sdgs/report/2019/

37. Uvarova, I., Atstaja, Dz. \& Korpa, V. (2019a). Challenges of the Introduction of Circular Business Models Within Rural SMEs of EU, International Journal of Economic Sciences VOL IX / No. 2 (accepted)

38. Uvarova, I., Atstaja, D., \& Vitola, A. (2019b). Circular Economy Driven Innovations Within Business Models of Rural SMEs. Proceedings of the International Scientific Conference "Society.Integration.Education". Volume VI, pp. $520-530$. 